\title{
A structural study of copper(II) carboxylates: Crystal structure and physical characterisation of $\left.\left[\mathrm{Cu}_{2}(2 \text {-bromopropanoato })_{4} \text { (caffeine }\right)_{2}\right]$
}

\author{
Fedor Valach, ${ }^{(1) *}$ Milan Melník, ${ }^{(2)}$ Gérald Bernardinelli, ${ }^{(3)}$ and Katharina M. Fromm ${ }^{(4)}$
}

Received August 30, 2005; accepted April 25, 2006

Published Online June 27, 2006

Based on the bond-valence sum model the continual transition between the bidentate and monodentate bonding mode of carboxylato group and minimum of $\mathrm{Cu}-\mathrm{O}$ bond lengths were estimated. The dependence of $\mathrm{Cu} \cdot \cdots \mathrm{Cu}$ separation on $\mathrm{Cu}-\mathrm{N}$ bond length in binuclear $\mathrm{Cu}$ (II) carboxylates with caffeine were derived and fitted to the observed data. The crystal structure of $\left[\mathrm{Cu}_{2} \text { (2-bromopropanoato }\right)_{4}$ (caffeine $\left.)_{2}\right]$ has been determined by X-ray crystallography. The structure consists of centrosymmetric binuclear units where the two $\mathrm{Cu}$ atoms are coordinated by four disordered bridging 2-bromopropionates and two caffeine ligands at the apices of a bicapped square prism. Both 2-bromopropionates show disorder of their $-\mathrm{Br}$ and $-\mathrm{CH}_{3}$ substituents. Stacking $\pi \cdots \pi$ interactions between the adjacent caffeine molecules link the complex units in 1-D networks. The binuclear structure of the studied compound is consistent with magnetic data and EPR spectrum.

KEY WORDS: Copper(II) carboxylates; halogenopropionates; caffeine; crystal structure; $\pi-\pi$ stacking interaction.

\section{Introduction}

Copper(II) carboxylates are interesting from both points of views, the central atom and the ligand properties. This class of compounds may contain mononuclear, binuclear and polynuclear structural units. ${ }^{1}$ The coordination sphere ge-

(1) Slovak University of Technology, Faculty of Chemical and Food Technology, Institute of Physical Chemistry and Chemical Physics, Radlinského 9, SK-812 37 Bratislava, Slovak Republic.

(2) Slovak University of Technology, Faculty of Chemical and Food Technology, Institute of Inorganic Chemistry, Technology and Materials, Radlinského 9, SK-812 37 Bratislava, Slovak Republic.

(3) Laboratory of X-ray Crystallography, University of Geneva, 24, quai E. Anserment, CH-1211 Genève 4, Switzerland.

(4) Department of Chemistry, University of Basel, Spitalstrasse 51, CH-4056 Basel, Switzerland.

* To whom correspondence should be addressed; e-mail: fedor. valach@stuba.sk ometry of $\mathrm{Cu}(\mathrm{II})$ complexes, in contrast to the carboxylato group reveals a certain flexibility. ${ }^{2}$ Correlations between interatomic distances, bond lengths or angles of binuclear $\mathrm{Cu}(\mathrm{II})$ complexes have been reported. ${ }^{1 \mathrm{a}, \mathrm{b}, 3}$ The bond-valence sum (BVS) model $^{4}$ provides a framework for the explanation of such structural correlations implying the mechanisms that produce them.

Carboxylate groups may coordinate to a $\mathrm{Cu}(\mathrm{II})$ atom through one $\mathrm{O}$ atom or through both $\mathrm{O}$ atoms. The last bonding mode may occur as chelate ligand bonded to one metal center or as bridging group connecting two metal centers. To our knowledge, until now, several crystal structures of $\mathrm{Cu}(\mathrm{II})$ halogenated propionates were solved. $\left[\mathrm{Cu}\left(\mathrm{CF}_{3} \mathrm{CF}_{2} \mathrm{COO}\right)_{2}(\mathrm{NITPhCl})_{2}\right] \quad$ (NIT$\mathrm{PhCl}=2$-(4-chloro-phenyl)-4,4,5,5-tetramethyl- 
imidazoline-1-oxyl-3-oxide $)^{5}(\mathbf{1})$ is mononuclear whereas $\left[\mathrm{Cu}_{2}\left(\mathrm{CF}_{3} \mathrm{CF}_{2} \mathrm{COO}\right)_{4}\left(\mathrm{NITmNO}_{2}\right)_{2}\right](\mathrm{NIT}$ $\mathrm{mNO}_{2}=2$-(3-nitrophenyl)-4,4,5,5-tetramethylimidazoline-1-oxyl-3-oxide $)^{6}$ (2) is a binuclear complex. The structures of $\left[\mathrm{Cu}_{2}\left(\mathrm{ClCH}_{2} \mathrm{CH}_{2}\right.\right.$ $\left.\mathrm{COO})_{4}\left(\mathrm{Ph}_{3} \mathrm{PO}\right)_{2}\right] \quad\left(\mathrm{Ph}_{3} \mathrm{PO}=\right.$ triphenylphosphine oxide) (3), ${ }^{7} \quad\left[\mathrm{Cu}_{2}\left(\mathrm{CH}_{3} \mathrm{CHClCOO}\right)_{4}\left(\mathrm{Ph}_{3} \mathrm{PO}\right)_{2}\right]^{8}$ (4) and $\left[\mathrm{Cu}_{2}\left(\mathrm{ClCH}_{2} \mathrm{CHClCOO}\right)_{4}(4-\mathrm{pic})_{2}\right]$ (4pic $=4$-picoline $)^{9}(5)$ consist of binuclear complex units. $\left[\mathrm{Cu}_{3}\left(\mathrm{CH}_{3} \mathrm{CHClCOO}\right)_{3}\left(\mathrm{Et}_{2} \mathrm{LO}\right)_{2}(\mathrm{OH})\right.$ $\left.\left(\mathrm{H}_{2} \mathrm{O}\right)\right]_{2}\left(\mathrm{Et}_{2} \mathrm{LO}=\text { 2-diethylaminoethanolate }\right)^{10}$ (6) complex is hexanuclear. Recently, the structures of monononuclear complexes $\left[\mathrm{Cu}\left(\mathrm{CH}_{3} \mathrm{CCl}_{2}\right.\right.$ $\left.\mathrm{COO})_{2}(3-\mathrm{mpyc})_{2}\right] \quad(3-\mathrm{mpyc}=$ methyl-3-pyridylcarbamate) at room temperature ${ }^{11}(7)$ and at 100 $\mathrm{K}^{12}(\mathbf{8})$ and $\left[\mathrm{Cu}_{2}\left(\mathrm{CH}_{3} \mathrm{CHBrCOO}\right)_{4}(2-\text { pyme })_{2}\right]$ (2-pyme $=2$-pyridylmethanol) at $208 \mathrm{~K}^{12}$ (9) were reported. The structure of $\left[\mathrm{Cu}\left(\mathrm{CH}_{3} \mathrm{CCl}_{2}\right.\right.$ $\mathrm{COO})_{2}(\text { dena })_{2}\left(\mathrm{H}_{2} \mathrm{O}\right)_{2} \cdot \mathrm{Cu}\left(\mathrm{CH}_{3} \mathrm{CCl}_{2} \mathrm{COO}\right)_{2}(\text { dena })_{2}$ $\left.\left(\mathrm{H}_{2} \mathrm{O}\right)\right](\text { dena }=\mathrm{N}, \mathrm{N} \text {-diethylnicotinamide })^{13}$ (10) consists of two chemically different units. The derivatives of propionic acid possess two quadribonded asymmetric carbon atoms ${ }^{14}$ in $2-(\alpha-)$ and $3-(\beta-)$ positions. But only in the compounds 2, 7 and $\mathbf{8}$ the positional disorder of propionate ligands was reported. $\left.\left[\mathrm{Cu}_{2}\left(\mathrm{CH}_{3} \mathrm{CHBrCOO}\right)_{4} \text { (caffeine }\right)_{2}\right]$ is the first example showing the chirality of halogenopropanoato carbon atom. A few crystal structures of copper(II) compounds with caffeine (3,7-dihydro-1,3,7-trimethyl-1,4-purine-2,6-dione) were resolved ${ }^{3 \mathrm{~b}, 15}$ in which the copper(II) atoms are five-coordinated. Eight of them ${ }^{3 \mathrm{~b}, 15 \mathrm{a}-\mathrm{g}}$ comprise the complex units of the composition $\left.\left[\mathrm{Cu}_{2} \mathrm{X}_{4} \text { (caffeine }\right)_{2}\right](\mathrm{X}=$ carboxylate $)$ with binuclear paddle-wheel cage structure. Four $\mathrm{X}$ anions function as bridging groups in a syn-syn arrangement. Nitrogen atom of caffeine assumes the apical position of the deformed tetragonal pyramid around copper(II) atom.

As a part of our investigations of halogenopropionates we present in this paper the crystal and molecular structure of the entitled compound. For $\mathrm{Cu}(\mathrm{II})$ carboxylates and described binuclear copper(II) complexes with caffeine the correlations of metal-ligand and metal-metal distances interpreted using BVS model is reported.

\section{Experimental}

\section{Preparation of complex}

The $\left[\mathrm{Cu}_{2} \text { (2-bromopropionato }\right)_{4}$ (caffeine $\left.)_{2}\right]$ was prepared as described earlier ${ }^{16}$ with the racemic 2-bromopropionate acid. The studied compound was prepared by adding a methanolic solution of caffeine to a stirred methanolic solution of $\mathrm{Cu}\left(\mathrm{CH}_{3} \mathrm{CHBrCOO}\right)_{2}$ in an equimolar ratio. After heating to reflux, the solution was left to cool and stand at room temperature. The green product that precipitated was isolated and washed with cold ethanol and dried at ambient temperature. The crude product was recrystallized from hot ethanol to yield green crystals.

Anal. Found: $\mathrm{Cu}, 11.3 ; \mathrm{C}, 30.0 ; \mathrm{H} 3.9 ; \mathrm{N}$, 9.95\%.

Calc. for $\mathrm{Cu}\left(\mathrm{CH}_{3} \mathrm{CHBrCOO}\right)_{2}$ (caffeine); $\mathrm{Cu}, 11.31$;, $29.94 ; \mathrm{H}, 3.95$ and N, 9.98\%.

\section{Crystal structure determination}

Intensity data were collected using a Stoe Ipds diffractometer at $200 \mathrm{~K}$. The diffraction intensities were corrected for Lorentz and polarisation effects. Absorption correction was applied. The calculations were made by the programs of X-RED software. ${ }^{17}$ The structure was solved by direct methods using the program MULTAN$87,{ }^{18}$ and refined by the full-matrix least-squares method (on $F$ ) using the program CRYLSQ ${ }^{19}$ (273 parameters). Hydrogen atoms of the caffeine moiety have been refined and blocked in the last cycles. The other hydrogen atoms have been refined with restraints on bond lengths and bond angles and blocked in the last cycles. The structure was drawn by the program ORTEP-3 for Windows. ${ }^{20}$ Crystal data and conditions of data collections are reported in Table 1. Selected geometrical parameters of the crystal structure are reported in Table 2.

\section{Magnetic and spectral measurements}

Electronic spectrum $\left(9000-50000 \mathrm{~cm}^{-1}\right)$ of the powdered sample in a Nujol mull was recorded 
Table 1. Summary of Crystal Data, Intensity Measurement and Structure Refinement for $\left[\mathrm{Cu}_{2} \text { (2-bromopropionato }\right)_{4}$ (caffeine) $\left.)_{2}\right]$

\begin{tabular}{ll}
\hline $\mathrm{CCDC}$ deposition number & 254424 \\
Empirical formula & $\mathrm{C}_{28} \mathrm{H}_{36} \mathrm{Br}_{4} \mathrm{Cu}_{2} \mathrm{~N}_{8} \mathrm{O}_{12}$ \\
Molecular weight & 1123.4 \\
Crystal size (mm) & $0.274 \times 0.172 \times 0.045$ \\
Crystal system & Triclinic \\
Space group & $P-1$ \\
$a(\AA)$ & $8.1483(10)$ \\
$b(\AA)$ & $9.8723(11)$ \\
$c\left(\AA^{\circ}\right)$ & $13.2438(13)$ \\
$\alpha\left(^{\circ}\right)$ & $108.605(12)$ \\
$\beta\left({ }^{\circ}\right)$ & $96.690(13)$ \\
$\gamma\left({ }^{\circ}\right)$ & $101.492(14)$ \\
$\mathrm{V}\left(\AA^{\circ}\right)$ & $970.7(3)$ \\
$Z$ & 1 \\
$D_{x}\left(\mathrm{Mg} \mathrm{m}^{-3}\right)$ & 1.922 \\
Wavelength $\left(\AA^{\circ}\right)$ & 0.71073 \\
$\mu($ Mo $K \alpha)\left(\mathrm{mm}^{-1}\right)$ & 5.28 \\
$T_{\min }, T_{\max }$ & $0.3510,0.7991$ \\
$(\mathrm{sin} \Theta / \lambda)_{\max }\left(\AA^{-1}\right)$ & 0.612 \\
No. of measured data & 12065 \\
No. of independent data & 3529 \\
No. of data in the refinements & 1825 \\
Weighting scheme $p^{a}$ & 0.0002 \\
Maximum $\Delta / \sigma$ & 0.002 \\
Max. and min. $\Delta \rho\left(\mathrm{e} . \AA^{-3}\right)$ & $0.89,-0.66$ \\
$S$ & 1.13 \\
$R, w R$ & $0.038,0.037$ \\
\hline$a$ &
\end{tabular}

$a_{w}=1 /\left(\sigma^{2}(F o)+p(F o)^{2}\right)$.

at room temperature on a Specord 200. Electron paramagnetic resonance (EPR) spectrum was recorded on the spectrometer Bruker ESP 300 operating at $\mathrm{X}$-band at room temperature, and equipped with the Bruker NMR gaussmeter ER $035 \mathrm{M}$ and Hewlett Packard microwave frequency counter HP5350B.

Magnetic measurements in the temperature range of $80-300 \mathrm{~K}$ were carried out on a sample of the complex at a magnetic field of $5 \mathrm{kG}$, using a Quantum Design SQUID Magnetometer (type MPMS-XL5). Corrections for diamagnetism of the constituting atoms were calculated using the Pascal constants, ${ }^{21}$ the value of $60.10^{-6} \mathrm{~cm}^{3} \mathrm{~mol}^{-1}$ was used as the temperatureindependent paramagnetism of a copper(II) atom. The effective magnetic moments were calculated from the expression

$$
\left.\mu_{\mathrm{eff}}=2.83 \sqrt{\chi_{M}^{\text {corr }} T} \quad \text { [B.M. }\right]
$$

Table 2. Selected Bond Distances $\left(\AA^{\circ}\right)$ and Angles and $\left(^{\circ}\right)$ for $\left[\mathrm{Cu}_{2} \text { (2-bromopropionato }\right)_{4}$ (caffeine) $\left.)_{2}\right]$ with e.s.d,'s in Parentheses

\begin{tabular}{llll}
\hline $\mathrm{Cu}-\mathrm{Cu}^{\mathrm{i}}$ & $2.694(1)$ & $\mathrm{Cu}-\mathrm{O}(2 \mathrm{a})$ & $1.953(6)$ \\
$\mathrm{Cu}-\mathrm{O}(1 \mathrm{a})$ & $1.968(6)$ & $\mathrm{Cu}-\mathrm{O}(1 \mathrm{~b})$ & $1.976(5)$ \\
$\mathrm{Cu}-\mathrm{N}(3)$ & $2.231(6)$ & $\mathrm{Cu}-\mathrm{O}\left(2 \mathrm{~b}^{\mathrm{i}}\right)$ & $1.967(4)$ \\
$\mathrm{C}(1 \mathrm{a})-\mathrm{C}(2 \mathrm{a})$ & $1.51(1)$ & $\mathrm{C}(1 \mathrm{~b})-\mathrm{C}(2 \mathrm{~b})$ & $1.511(9)$ \\
$\mathrm{C}(2 \mathrm{a})-\mathrm{Br}(1 \mathrm{a})$ & $1.929(7)$ & $\mathrm{C}(2 \mathrm{~b})-\mathrm{Br}(1 \mathrm{~b})$ & $1.911(9)$ \\
$\mathrm{O}(1 \mathrm{~b})-\mathrm{Cu}-\mathrm{O}\left(2 \mathrm{a}^{\mathrm{i}}\right)$ & $89.4(3)$ & $\mathrm{O}(1 \mathrm{~b})-\mathrm{C}(1 \mathrm{~b})-\mathrm{O}(2 \mathrm{~b})$ & $126.7(6)$ \\
$\mathrm{O}(1 \mathrm{~b})-\mathrm{Cu}-\mathrm{O}\left(2 \mathrm{~b}^{\mathrm{i}}\right)$ & $167.1(3)$ & $\mathrm{O}(1 \mathrm{~b})-\mathrm{C}(1 \mathrm{~b})-\mathrm{C}(2 \mathrm{~b})$ & $116.5(7)$ \\
$\mathrm{O}(1 \mathrm{a})-\mathrm{C}(1 \mathrm{a})-\mathrm{O}(2 \mathrm{a})$ & $127.1(8)$ & $\mathrm{O}(2 \mathrm{~b})-\mathrm{C}(1 \mathrm{~b})-\mathrm{C}(2 \mathrm{~b})$ & $116.7(7)$ \\
$\mathrm{O}(1 \mathrm{a})-\mathrm{C}(1 \mathrm{a})-\mathrm{C}(2 \mathrm{a})$ & $115.9(7)$ & $\mathrm{C}(1 \mathrm{~b})-\mathrm{C}(2 \mathrm{~b})-\mathrm{Br}(1 \mathrm{~b})$ & $104.4(6)$ \\
$\mathrm{O}(2 \mathrm{a})-\mathrm{C}(1 \mathrm{a})-\mathrm{C}(2 \mathrm{a})$ & $117.0(7)$ & $\mathrm{C}(1 \mathrm{~b})-\mathrm{C}(2 \mathrm{~b})-\mathrm{C}(3 \mathrm{~b})$ & $118(1)$ \\
$\mathrm{Br}(1 \mathrm{a})-\mathrm{C}(2 \mathrm{a})-\mathrm{C}(3 \mathrm{a})$ & $111(1)$ & $\mathrm{Br}(1 \mathrm{~b})-\mathrm{C}(2 \mathrm{~b})-\mathrm{C}(3 \mathrm{~b})$ & $108(1)$ \\
\hline
\end{tabular}

Symmetry code: (i) $2-x, 1-y, 1-z$.

The EPR spectrum was measured using either a digitized Bruker ER 200 E SRC with an internal marked for determining the frequency.

\section{Results and discussion}

The crystal structure of the entitled compound consists of a centrosymmetric binuclear complex where the two $\mathrm{Cu}$ atoms are coordinated by eight oxygen atoms of four bridging 2bromopropionates. Two nitrogen atoms of two caffeine ligands are located at the apex of a bicapped square prism. The structure of the binuclear complex is shown in Fig. 1. Each $\mathrm{Cu}$ (II) is five coordinated by four carboxylic $\mathrm{O}$ atoms in an equatorial plane (maximum deviation of the mean plane passing through the four oxygen atoms: $0.001(5) \AA$ ) and axially by one $\mathrm{N}$ atom from the molecule of caffeine, to give a tetragonal pyramid. The displacement of the $\mathrm{Cu}$ atom from the equatorial plane toward the apical atom N(3) [0.221(1) $\AA]$ is comparable with that found for other $\mathrm{Cu}$ (II) carboxylates. $^{1 \mathrm{a}, 22}$ The distance between the two basal planes of the studied compound as defined by Yablokov et al..$^{23}$ is 2.247(1) $\AA$.

Both 2-bromopropionato ligands show a disorder by permutation of their $-\mathrm{Br}$ and $-\mathrm{CH}_{3}$ substituents leading to an inversion of configuration at the $\mathrm{C}(2)$ position. The disorders were resolved by refining the population parameter of the major bromine substituent and fixing the sum with 


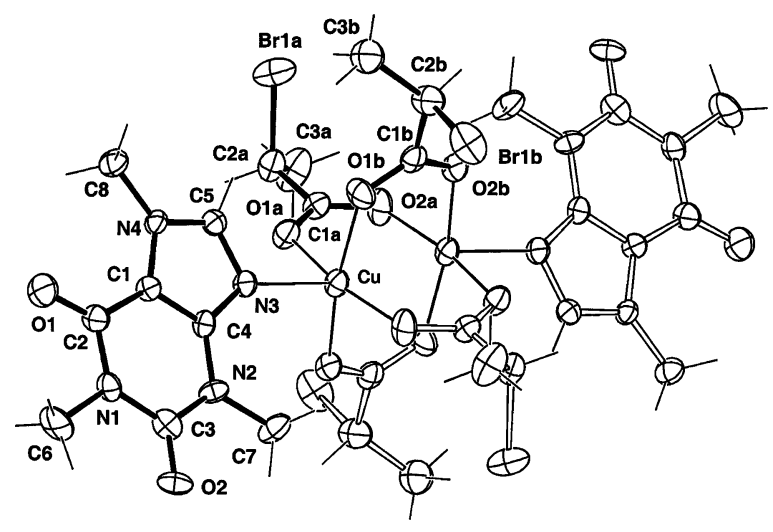

Fig. 1. Ortep view of the crystal structure of $\left[\mathrm{Cu}_{2}(2-\right.$ bromopropionato $)_{4}$ (caffeine $)_{2}$ ] showing the atom numbering of the asymmetric unit (black bonds) and the part of the binuclear complex generated by a centre of inversion (white bonds). Ellipsoids are represented with $50 \%$ probability level. Only the major disordered 2-bromopropinates are represented.

the minor to unity. These population parameters are also applied to the involved methyl C(3) and hydrogen atoms. The refinement of such a model (see Fig. 2) shows final disorder ratios of 0.907(4)/0.093(4) and 0.650(4)/0.350(4) for 2bromopropionates $\mathbf{a}$, and $\mathbf{b}$ respectively. The bond lengths and angles of 2-bromopropionate groups do not show significant deviations to those found in the structure of compound 9. It should be noted that a refinement in the space group $P 1$, led to similar distribution of the population parameters and a Flack parameter ${ }^{25} x=0.48(7)$ confirming that the structure is centrosymmetric.

The caffeine ligand of $\left[\mathrm{Cu}_{2}\right.$ (2-bromopropionato $)_{4}$ (caffeine $)_{2}$ ] complex is slightly deviated from planarity (maximum deviation $=0.052 \AA$ for $\mathrm{C}(3)$ ) and is involved in intermolecular $\pi \cdots \pi$ stacking interactions ${ }^{26}$ through a centre of inversion (mean interplane distance $=3.56(3) \AA$ ) connecting the complex units into a infinite chain along c direction. The dihedral angle between the 6- and 5-membered rings of the caffeine moiety is $2.1(4)^{\circ}$. The methyl groups of caffeine molecule are slightly deviated from the planes of five- and six-membered rings. The torsion angles

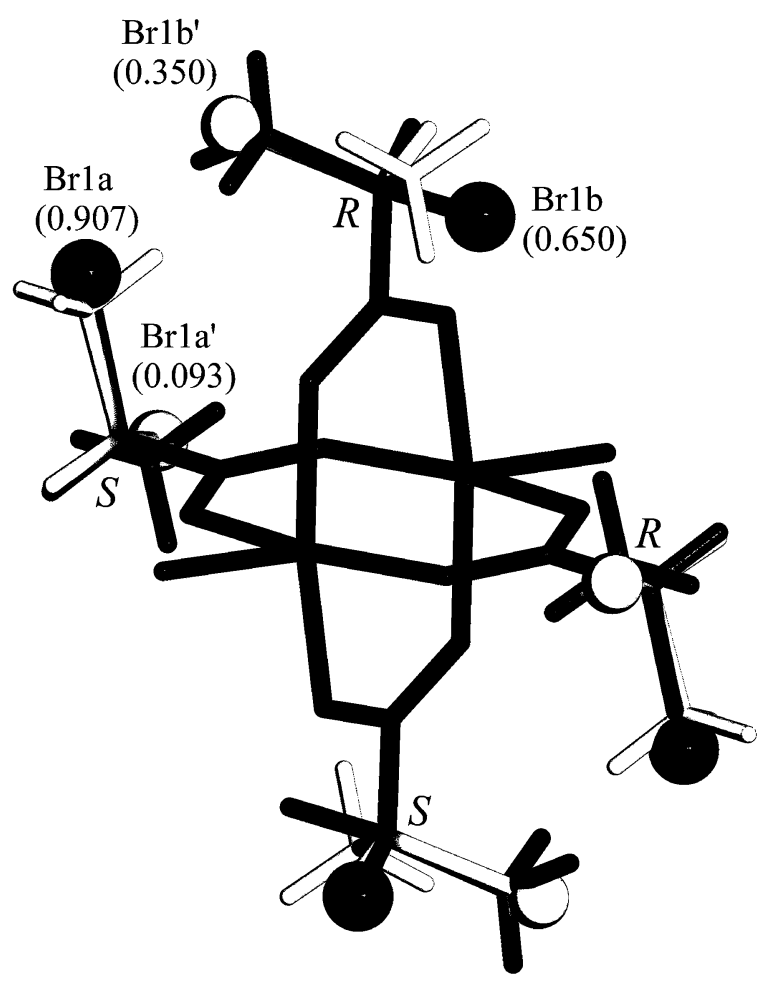

Fig. 2. Perspective view of the crystal structure of $\left[\mathrm{Cu}_{2}(2-\right.$ bromopropionato $)_{4}$ (caffeine $)_{2}$ ] (caffeine moieties are omitted for clarity) showing the disorder of the bromopropionates substituents. Bromine atoms are represented by spheres. The population parameters of the major (black) and minor (white) moieties are reported in parenthesis and the relative configuration at the $\mathrm{C}(2)$ centers $^{24}$ of the major part are mentioned.

$\mathrm{C}(8)-\mathrm{N}(4)-\mathrm{C}(1)-\mathrm{C}(2)$ and $\mathrm{C}(7)-\mathrm{N}(2)-\mathrm{C}(4)-\mathrm{N}(3)$ are $9(1)^{\circ}$ and $2.4(9)^{\circ}$, respectively.

The $\mathrm{Cu}_{2}(\mathrm{COO})_{4}$ cage of studied compound is geometrically very close to the same cages of binuclear complexes 3-5. The coordination of atom $\mathrm{Cu}$ for these complexes is square pyramidal. But the geometry around each atom $\mathrm{Cu}$ of the 2-bromopropionato complex 9 is distorted tetragonal bipyramid with coordination number $4+2$. In Fig. 3 is shown the correlation between the $\mathrm{Cu}-\mathrm{O}$ and $\mathrm{O}-\mathrm{C}$ bond lengths of the independent $\mathrm{Cu}-\mathrm{O}-\mathrm{C}$ moieties. The data for binuclear copper complexes were collected by Cambridge Structural Database (CSD), ${ }^{27}$ Version 2.3.8. The function (2) for non-linear regression of the correlation in Fig. 3 was derived using the logarithmic 


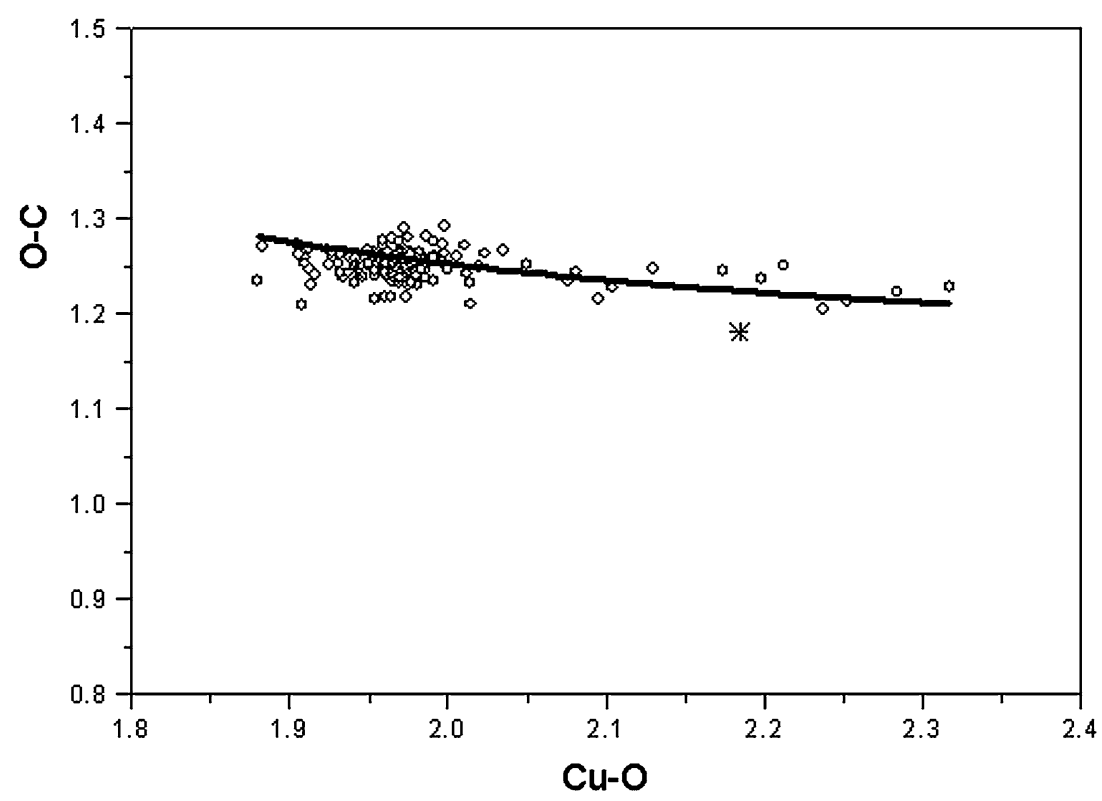

Fig. 3. Dependence of between the $\mathrm{Cu}-\mathrm{O}$ and $\mathrm{C}-\mathrm{O}$ bond lengths (in $\AA$ ) of the independent $\mathrm{Cu}-\mathrm{O}-\mathrm{C}$ moieties in the $\mathrm{Cu}_{2}(\mathrm{COO})_{4}$ cages with the scatterogram of compounds from CSD with crystallographic $R$-factors less then 0.06 ( $\circ$ ). For chemically equivalent bonds of the compounds $\left.\mathbf{3}-\mathbf{5},\left[\mathrm{Cu}_{2}\left(\mathrm{CH}_{3} \mathrm{CHBrCOO}\right)_{4} \text { (caffeine }\right)_{2}\right]$ and the compound $\mathbf{2}\left({ }^{*}\right)$ $R=0.17$ and $\mathrm{w} R=0.18$, the mean values are shown. The coefficient of linear correlation is -0.314 .

formula $^{4 \mathrm{a}}$ for $\mathrm{O}-\mathrm{C}$ bond valence and the formula based on orbital metal-ligand interaction of $\mathrm{Cu}-\mathrm{O}$ bond: ${ }^{4 \mathrm{i}}$

$$
\begin{aligned}
r_{\mathrm{O}-\mathrm{C}}= & R^{*}-b \ln \left(V^{*}-\frac{\alpha_{1}}{r_{\mathrm{Cu}-\mathrm{O}}}-\frac{\alpha_{2}}{r_{\mathrm{Cu}-\mathrm{O}}^{2}}\right. \\
& \left.-\frac{\alpha_{3}}{r_{\mathrm{Cu}-\mathrm{O}}^{3}}-\frac{\alpha_{4}}{r_{\mathrm{Cu}-\mathrm{O}}^{4}}-\frac{\alpha_{5}}{r_{\mathrm{Cu}-\mathrm{O}}^{5}}\right)
\end{aligned}
$$

$r_{\mathrm{O}-\mathrm{C}}$ and $r_{\mathrm{Cu}-\mathrm{O}}$ are $\mathrm{O}-\mathrm{C}$ and $\mathrm{Cu}-\mathrm{O}$ bond lengths. Variable $V^{*}$ is the valence of the atom $\mathrm{O}$ and $R^{*}$ is the bond valence parameter ${ }^{4 \mathrm{c}}$ of the $\mathrm{C}-\mathrm{O}$ bond and $b$ is commonly accepted constant equal to $0.37 \AA^{4 \mathrm{~d}} . \alpha_{\mathrm{i}}$ are constants of the bond valence formula for the $\mathrm{Cu}-\mathrm{O}$ bond. The fitted parameters are $R^{*}=1.51(3) \AA$ and $V^{*}=2.4(2)$. This correlation implies very weak influence of $\mathrm{Cu}-\mathrm{O}$ bond on $\mathrm{O}-\mathrm{C}$ bond lengths of carboxylato group.

The lengths of shorter and longer $\mathrm{Cu}-\mathrm{O}$ bonds within the chelate tetrametallocycle containing the chelated carboxylato group in this work are assigned: $r_{S}$ and $r_{L}$ respectively. Figure 4 shows the correlation $r_{\mathrm{S}} v s . r_{\mathrm{L}}$ for hexacoordinated copper(II) carboxylates. The data were collected from Cambridge Structural Database (CSD), ${ }^{27}$ Version 2.3.8. Only the structures solved from the single crystal data with crystallographic $R$-factor less than 0.05 were involved. The structures with at least one disordered atom were excluded. A continuous range of states occur between the monodentate and bidentate coordination of carboxylate group to one $\mathrm{Cu}$ atom which can be explained as the manifestation of coordination sphere plasticity. ${ }^{2 a}$ The function (3) which express the correlation shown in Fig. 4 was derived from the BVS model. For the shorter $\mathrm{Cu}-\mathrm{O}$ bond, the bond valence function based on the orbital metal-ligand interaction was used. The best fit was achieved using the formula for the bond valence of longer $\mathrm{Cu}-\mathrm{O}$ bond $s_{L}=\left(R_{o} / r_{L}\right)^{N}$ in the range of $r_{L}=2.6-3.07 \AA$. Within this range 


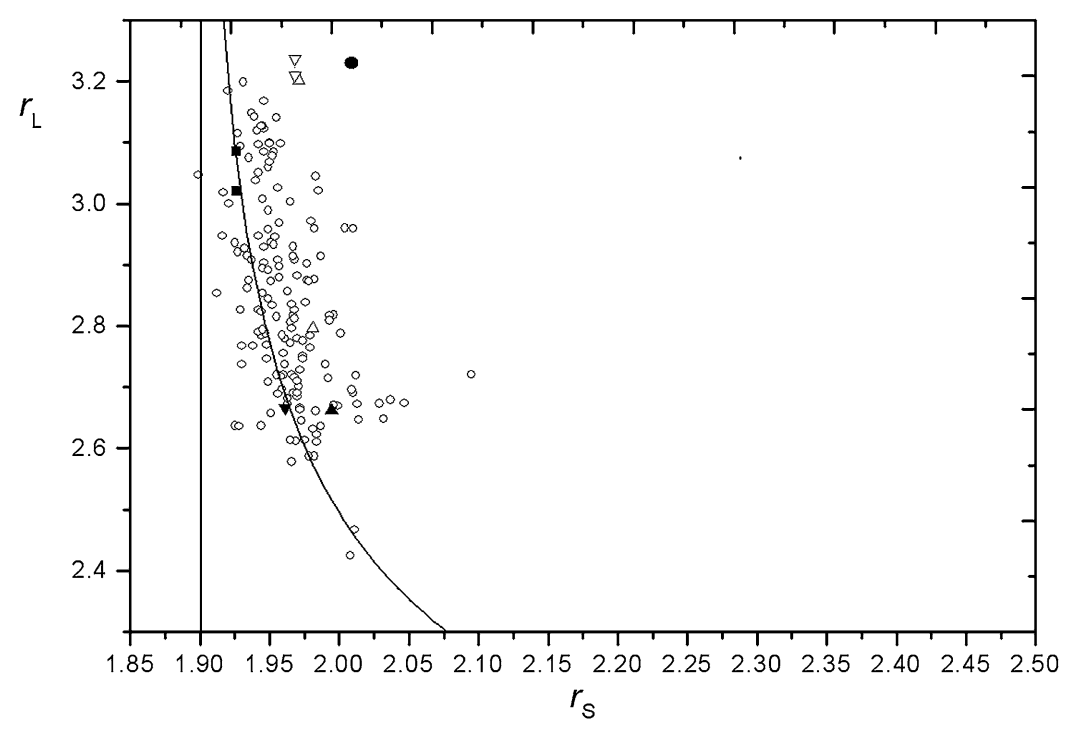

Fig. 4. Dependence between $r_{L}$ and $r_{S}$ values (in $\AA$ ) with the scatterogram from CSD data for hexacoordinated copper(II) carboxylates (open circles). Spearman rank-

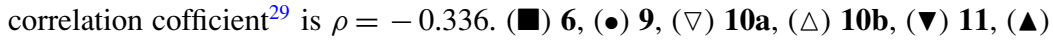
12.

is the bond valence function $s_{L}$ greater than bond valence function based on orbital interaction. ${ }^{4 \mathrm{i}} R_{O}$ and $N$ are constants. ${ }^{4 \mathrm{a}}$ The bond valence function $s_{L}$ can be derived with a purely ionic approach. ${ }^{4 \mathrm{e}, \mathrm{g}}$ On the other hand, there is a close correlation between the bond valence (bond strengths) $s_{L}$ and the metal-oxygen covalence. ${ }^{4 \mathrm{~h}}$

$$
\begin{aligned}
r_{L}= & R_{o}\left[\frac{\alpha_{1}}{r_{S}}+\frac{\alpha_{2}}{r_{S}^{2}}+\frac{\alpha_{3}}{r_{S}^{3}}+\frac{\alpha_{4}}{r_{S}^{4}}+\frac{\alpha_{5}}{r_{S}^{5}}\right. \\
& \left.+2-V_{o}^{*}\right]^{-1 / N}
\end{aligned}
$$

Variable $V_{o}^{*}$ is the contribution of remaining copper-ligand bonds to the bond valence sum around the central atom. ${ }^{28}$ The standard statistical procedure for the test of correlation significance and goodness of fit was used. ${ }^{29}$ The fitted value of $V_{o}^{*}$ is 1.493(2). The curve of function (3) approaches the minimum of short $\mathrm{Cu}-\mathrm{O}$ bond length asymptotically at $1.90(5) \AA$ (Fig. 4). Such interatomic distance occurs in compex 1 [1.903(2) A]], and consequently the pentafluoropropionate ligand of this complex is monodentate. In the range where $r_{L}$ is greater than $3.1 \AA, r_{S}$ is almost insensitive towards further increase of the value of $r_{S}$. The carboxylato groups of the studied compounds with $r_{L}>3.1 \AA$ are monodentate. The points of compound 9 reveal the greatest deviation from the fitted curve which can be explained by the relative strong hydrogen bonds of uncoordinated oxygen atoms to the methanol hydrogen atoms of 2-pyridylmethanol. The structure of compound $\mathbf{1 0}$ contains two kinds of independent complex units mutually bonded by the hydrogen bonds. The 2,2-chloropropionate anions of the unit $\left[\mathrm{Cu}\left(\mathrm{CH}_{3} \mathrm{CCl}_{2} \mathrm{COO}\right)_{2}(\text { dena })_{2}\left(\mathrm{H}_{2} \mathrm{O}\right)\right]$ (10a) are monodentate. $\mathrm{Cu}(\mathrm{II})$ atom of $\left[\mathrm{Cu}\left(\mathrm{CH}_{3} \mathrm{CCl}_{2} \mathrm{COO}\right)_{2}(\text { dena })_{2}\left(\mathrm{H}_{2} \mathrm{O}\right)_{2}\right](\mathbf{1 0 b})$ is coordinated by the monodentate and bidentate 2,2chloropropionate anions. Similarly as in complex 9 the uncoordinated oxygen atoms of monodentate 2,2-chloropropionate anion are bonded via hydrogen bonds to the water molecule of the inner copper(II) coordination sphere. The pentafluoroand 2-chloropropionate anions of complex 6 are monodentate with very weak $\mathrm{Cu} \cdots \mathrm{O}$ interactions. 


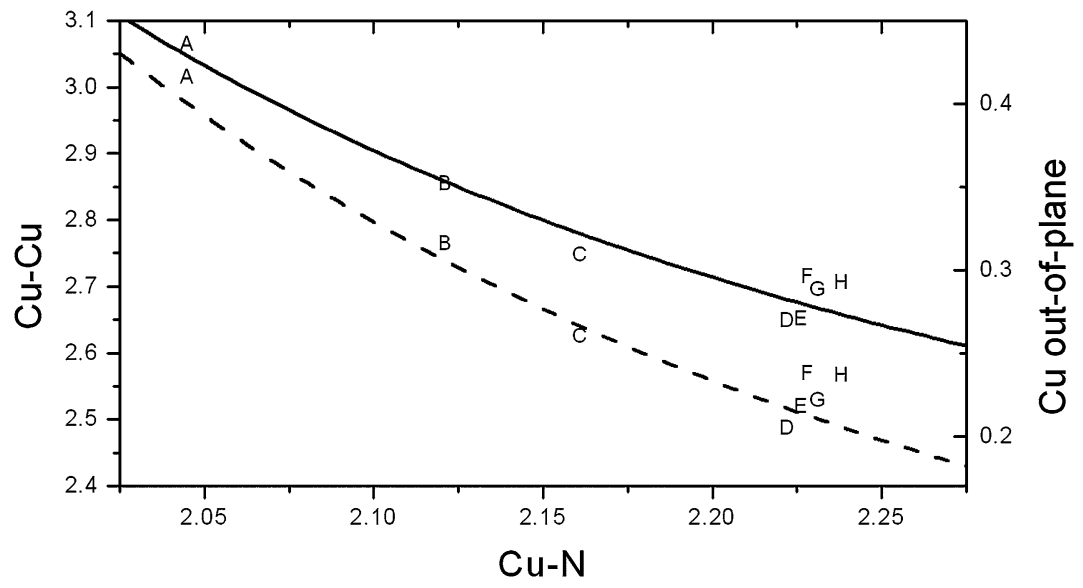

Fig. 5. The dependences of $\mathrm{Cu} \cdots \mathrm{Cu}$ separation (full line) and the deviations of the copper(II) cation from the basal $\mathrm{O}_{4}$ plane in $\mathrm{CuO}_{4} \mathrm{~N}$ chromophore (dashed line) on $\mathrm{Cu}-\mathrm{N}$ bond length with the scatter plots of the dada in Table 3 .

The room temperature magnetic moment for the $\left[\mathrm{Cu}_{2} \text { (2-bromopropionato }\right)_{4}$ (caffeine $\left.)_{2}\right]$ complex of $\mu_{\text {eff }}=1.48$ B.M. is lower than $d^{9}$ spin - only moment, $\mu_{\mathrm{eff}}=1.73$ B.M., and is similar to those observed for other binuclear $\mathrm{Cu}$ (II) complexes of the type $\left[\mathrm{Cu}_{2}(\mathrm{RCOO})_{4} \mathrm{~L}_{2}\right]^{30}$ with antiferromagnetic super-exchange interaction between the copper(II) atoms. The magnetic moment of the complex at $80 \mathrm{~K}$ decreases to the value of 0.42 B.M., as a consequence of depopulation of the excited triplet $(S=1)$ state $^{31}$

The solid electronic spectrum of the complex shows a broad absorption band (band I) in the visible region at $13500 \mathrm{~cm}^{-1}$, which could be assigned to a $d_{x^{2}, y^{2}} \rightarrow d_{x^{2}-y^{2}}$ transition. Moreover, the spectrum displays a shoulder at $26000 \mathrm{~cm}^{-1}$ (band II). Band II has been assigned to a chargetransfer LMCT absorption and is believed to be indicative of a binuclear complex. ${ }^{32}$

The EPR spectrum is characteristic of a triplet state which can be characterized by the singlet-triplet separation $|\mathrm{J}|$. The spectrum of the complex may be interpreted in terms of the spin

$\hat{H}=\beta B g \bar{S}+D\left[S_{y}^{2}-\frac{1}{3} S(S+1)\right]+E\left[S_{x}^{2}-S_{z}^{2}\right]$

where $D$ is the zero-field splitting parameter, $x$, $y$ and $z$ are the principal axes of the coordinate system fixed with respect to the $\mathrm{Cu} \cdot \mathrm{Cu}$ contact, and the other symbols have their usual meaning. ${ }^{33}$ The spin parameters are $g_{\perp}=2.045, g_{\|}=2.325$, $|D|=0.332 \mathrm{~cm}^{-1}$ and $E=0.005 \mathrm{~cm}^{-1}$. The energy separation $(-2 J)$ between the triplet and singlet states of $310 \mathrm{~cm}^{-1}$ is similar to those found in the series of binuclear copper(II) carboxylates. $22 \mathrm{a}, 30 \mathrm{a}$

In Fig. 5 are shown the $\mathrm{Cu} \cdots \mathrm{Cu}$ distances plotted against the $\mathrm{Cu}-\mathrm{N}$ distances of $\left.\left[\mathrm{Cu}_{2} \mathrm{X}_{4} \text { (caffeine }\right)_{2}\right]$ complexes listed in Table 3. The $\mathrm{Cu}-\mathrm{O}$ bond length of these compounds reveals only small variation. The mean value of $\mathrm{Cu}-\mathrm{O}$ bond lengths of compounds in Table 3 is $1.97 \pm 0.04 \AA$. If $\mathrm{Cu}-\mathrm{O}$ distances are kept constant the expression (5) holds which was derived from the BVS model. The best fit of correlation shown in Fig. 5 was achieved using the exponential formula for the bond valence of $\mathrm{Cu}-\mathrm{N}, \mathrm{Cu}-\mathrm{O}$ bonds $\mathrm{s}^{4 \mathrm{c}}$ and formula $s_{\mathrm{Cu} \cdots \mathrm{Cu}}=\left(R^{*} / r_{\mathrm{Cu} \cdots \mathrm{Cu}}\right)^{N *}$ for the bond valence of $\mathrm{Cu} \cdots \mathrm{Cu}$ contact. $r_{\mathrm{Cu} \cdots \mathrm{Cu}}$ is internuclear $\mathrm{Cu} \cdots \mathrm{Cu}$ distance and $R^{*}, N^{*}$ are constants.

$$
\begin{aligned}
r_{\mathrm{Cu} \cdots \mathrm{Cu}}= & R^{*}\left[2-\bar{s}_{\mathrm{Cu}-\mathrm{O}}\right. \\
& \left.-\exp \left(\frac{R_{\mathrm{Cu}-\mathrm{N}}-r_{\mathrm{Cu}-\mathrm{N}}}{b}\right)\right]^{-1 / N^{*}}
\end{aligned}
$$


Table 3. Selected structural parameters of $\left.\left[\mathrm{Cu}_{2} \mathrm{X}_{4} \text { (caffeine }\right)_{2}\right]$ complexes

\begin{tabular}{llllrlll}
\hline $\mathrm{X}$ & $\mathrm{Cu}-\mathrm{N}(\AA)$ & $\mathrm{Cu} \cdots \mathrm{Cu}(\AA)$ & $\mathrm{Cu}$ out of plane deviation $(\AA)$ & $\Phi\left(^{\circ}\right)$ & $R^{a}$ & Mark & Ref \\
\hline Trichloroacetato $^{b}$ & $2.045(2)$ & $3.0622(7)$ & $0.415(1)$ & $19.11(9)$ & 0.035 & $\mathrm{~A}$ & $3 \mathrm{~b}$ \\
Trichloroacetato $^{b}$ & $2.121(6)$ & $2.852(2)$ & $0.315(1)$ & $12.7(2)$ & 0.068 & $\mathrm{~B}$ & $15 \mathrm{a}$ \\
Benzoylformato $^{b}$ & $2.161(4)$ & $2.745(1)$ & $0.259(1)$ & $4.5(2)$ & 0.067 & $\mathrm{C}$ & $15 \mathrm{~b}$ \\
Benzoato $^{c}$ & $2.222(3)$ & $2.6470(7)$ & $0.204(1)$ & $81.6(1)$ & 0.053 & $\mathrm{D}$ & $15 \mathrm{c}$ \\
Naproxenato $^{2.226(6)}$ & $2.649(2)$ & $0.217(1)$ & $79.8(2)$ & 0.071 & $\mathrm{E}$ & $15 \mathrm{~d}$ \\
Monochloroacetato $^{2}$ & $2.23(1)$ & $2.713(2)$ & $0.237(1)$ & $81.7(3)$ & 0.067 & $\mathrm{~F}$ & $15 \mathrm{e}$ \\
2-bromopropionato & $2.231(6)$ & $2.694(1)$ & $0.221(1)$ & $79.9(2)$ & 0.038 & $\mathrm{G}$ & This work \\
2-iodobenzoato & $2.238(3)$ & $2.704(6)$ & $0.236(1)$ & $81.6(1)$ & 0.039 & $\mathrm{H}$ & $15 \mathrm{f}, \mathrm{g}$ \\
\hline
\end{tabular}

${ }^{a} R=\sum|| F_{\mathrm{o}}|-| F_{\mathrm{c}}|| / \sum\left|F_{\mathrm{o}}\right|$.

${ }^{b}$ Dibenzene solvate.

${ }^{c}$ Caffeine solvate.

$\bar{s}_{\mathrm{Cu}-\mathrm{O}}$ is the mean value of $\mathrm{Cu}-\mathrm{O}$ bond valences for the compounds listed in Table 3 and $r_{\mathrm{Cu}-\mathrm{N}}$ is internuclear $\mathrm{Cu}-\mathrm{N}$ distance. $R_{\mathrm{Cu}-\mathrm{N}}$ is bond valence parameter of $\mathrm{Cu}-\mathrm{N}$ bond. ${ }^{4 \mathrm{c}}$ The fitted values of $R^{*}$ and $N^{*}$ are 4.1(1) and 0.71(6). In Fig. 5 is the graph of the function (5) plotted by the full line. The out-of-plane deviation of atom $\mathrm{Cu}$ for the binuclear complex unit with the center of symmetry between two $\mathrm{Cu}$ atoms in cage is equal to $\left(r_{\mathrm{Cu} \cdots \mathrm{Cu}}-\right.$ basal plane-basal plane distance $) / 2$. The mean value of basal plane-basal plane distance of $2.22 \pm 0.03 \AA^{1 \mathrm{a}}$ was used for calculations (dashed line in Fig. 5). The strong correlation between $\mathrm{Cu} \cdots \mathrm{Cu}$ distance and out-of-plane deviation of atom $\mathrm{Cu}$ has been reported. $2 \mathrm{~b}$ The correlations in Fig 5. fitted by described BVS model suggest predominantly electrostatic nature of $\mathrm{Cu} \cdot \mathrm{Cu}$ interaction which is consistent with negligibly weak $\mathrm{Cu} \cdot \mathrm{Cu}$ spin-exchange compared to the spin superexchange through the bridging carboxylates. ${ }^{34}$ The coordination copper(II) geometry of these complexes is square-pyramid deformed toward the trigonal bipyramid. Such deformation can be expressed by the angle between $\mathrm{Cu}-\mathrm{N}$ bond line and basal least-squares plane $(\Phi), \mathrm{Cu}$ out-of plane deviation and $\mathrm{Cu}-\mathrm{N}$ bond length (Table 3 ). For the complexes D-H is such deformation almost equal. But for the complexes A-C deformation of copper(II) coordination geometry increase with elongation of $\mathrm{Cu} \cdots \mathrm{Cu}$ separation. The dependences shown in Fig. 5 may be caused by the integral effect of antiferromagnetic spin-exchange interaction between the to copper(II) atoms through the four carboxylate ions, ${ }^{3 \mathrm{~b}}$ electrostatic $\mathrm{Cu} \cdots \mathrm{Cu}$ interaction within the binuclear cage, and crystal packing.

\section{Conclusions}

Halogenopropionate anions can act in copper(II) complexes as bridging ligands, chelate ligands or monodentate ligand. Within a fourmembered metallocycles with chelated carboxylic ligands the interatomic distances $\mathrm{Cu}-\mathrm{O}\left(r_{S}\right.$ and $\left.r_{L}\right)$ are unambiguously mutually dependent. The dependence $r_{S}$ vs. $r_{L}$ is expressed by the equation (3). Increase of the shorter interatomic $\mathrm{Cu}-\mathrm{O}$ distance $\left(r_{S}\right)$ leads to a strengthening of the longer $\mathrm{Cu}-\mathrm{O}$ bond, and consequently, to a shortening of the longer $\mathrm{Cu}-\mathrm{O}$ distance $\left(r_{L}\right)$ and vice versa. At the minimal shorter interatomic distance $\mathrm{Cu}-\mathrm{O}\left(r_{S}\right)$ being $1.92(3) \AA$ long no further increase of the longer $\mathrm{Cu}-\mathrm{O}$ distance $\left(r_{L}\right)$ takes place. There is a continual transition between the bidentate and monodentate bonding mode of the carboxylato group. Within the $\mathrm{Cu}_{2}(\mathrm{COO})_{4}$ cage of binuclear $\mathrm{Cu}$ (II) complex the bond lengths $\mathrm{C}-\mathrm{O}$ slightly depend on the interatomic distance $\mathrm{Cu}-\mathrm{O}$ of the same $\mathrm{Cu}-\mathrm{O}-\mathrm{C}$ moiety. This dependence $\left(r_{\mathrm{Cu}-\mathrm{O}} v s . r_{\mathrm{C}-\mathrm{O}}\right)$ is expressed by the equation (2). For the complexes $\left.\left[\mathrm{Cu}_{2} \mathrm{X}_{4} \text { (caffeine }\right)_{2}\right]$ listed in Table 3 the dependence of $\mathrm{Cu}-\mathrm{N}$ distance $v s . \mathrm{Cu} \cdots \mathrm{Cu}$ separation is expressed by the 
equation (5). If the bond lengths $\mathrm{Cu}-\mathrm{O}$ are kept constant any elongation of the $\mathrm{Cu} \cdot \mathrm{Cu}$ separation leads to the shortening of $\mathrm{Cu}-\mathrm{N}$ distance and vice versa. The novel 2-bromopropionato copper(II) complex with caffeine has been prepared and characterized. The crystal structure of $\left[\mathrm{Cu}_{2}\right.$ (2-bromopropionato) (caffeine) $\left._{2}\right]$ consists of binuclear units connected by the stacking $\pi \cdots \pi$ interactions between adjacent molecules of caffeine in 1-D networks. $-\mathrm{Br}$ and $-\mathrm{CH}_{3}$ substituents of 2-bromopropionato ligands are disordered in major and minor positions. The asymmetric 2-carbon atoms exhibit the chirality of major and invert chirality of minor atoms. The molecular structure and nonbonding character of $\mathrm{Cu} \cdot \mathrm{Cu}$ contacts within each unit are consistent with the magnetic data and EPR spectra of the substance.

\section{Acknowledgements}

This work was sponsored by the grants 1/0056/03 and 1/3572/06 of the Slovak Grant Agency for Science (VEGA). The authors gratefully acknowledge the Professor Alan F. Williams for his helpful discussions.

\section{References}

1. (a) Melník, M. Coord. Chem. Rev. 1982, 42, 259. (b) Catterick, J.; Thornton, P. Adv. Inorg. Chem. Radiochem. 1977, 20, 291. (c) Melník, M. Coord. Chem. Rev. 1981, 36, 1.

2. (a) Gažo, J.; Bersuker, I.B.; Garaj, J.; Kabešová, M.; Kohout, J.; Langfelderová, H.; Melník, M.; Serátor, M.; Valach, F. Coord. Chem. Rev. 1976, 19, 253. (b) Gažo, J.; Boča, R.; Jóna, E.; Kabešová, M.; Macášková, Ľ.; Šima, J.; Pelikán, P.; Valach, F. Coord. Chem. Rev. 1982, 43, 87.

3. (a) Koh, Y.B.; Christoph, G.G. Inorg. Chem. 1979, 18, 1122. (b) Uekusa, H.; Ohba, S.; Tokii, T.; Muto, Y.; Kato, M.; Husebye, S.; Steward, O.W.; Chang, Shih-Chi; Rose, J.P.; Pletcher, J.F.; Suzuki, I. Acta Crystallogr. B 1992, 48, 650.

4. (a) Brown, I.D. Structure and Bonding in Crystals. Vol. 2; M. O‘Keeffe, A. Navrotski, Eds.; Academic Press: New York, 1981; pp. 1-30. (b) O'Keeffe, M. Struct. Bonding (Berlin). 1989, 71, 162. (c) Breese, N.E.; O‘Keeffe, M. Acta Crystallogr. B 1991, 47, 192. (d) Brown, I.D.; Alternatt, D. Acta Crystallogr. B 1985, 41, 244. (e) Urusov, U.S. Acta Crystallogr. B 1995, 51, 641. (f) Gopinathan, M.S.; Jug, K. Theoret. Chim. Acta (Berlin) 1983, 63, 497. (g) Naskar, J.P.; Hati, S.; Datta, D. Acta Crystallogr. $B$ 1997, 53, 885. (h) Brown, I.D.; Shannon, R.D. Acta Crys- tallogr. A 1973, 29, 266. (i) Valach, F. Polyhedron 1999, 18 , 699. (j) Brown, I.D. The Chemical Bond in Inorganic Chemistry: The Bond-Valence Model; Oxford University Press: Oxford, 2002.

5. Jiang, Z.-H.; Sun, B.-W.; Liao, D.-Z.; Wang, G.-L.; Dahan, F.; Tuchangues, J.P. Inorg. Chim. Acta 1998, 279, 69.

6. Zhang, L.; Li, S.-Q.; Sun, B.-W.; Liao, D.-Z.; Jiang, Z.-H.; Yan, S.-P.; Wang, G.-L.; Yao, X.-K.; Wang, H.-G. Polyhedron 1999, $18,781$.

7. Sharock, P.; Melník, M.; Belangier-Gariepy, F.; Beachamp, L. Can. J. Chem. 1985, 63, 2564.

8. Koreň, B.; Sivý, P.; Valach, F.; Melník, M.; Ječný, J. Acta Crystallogr. C 1988, 44, 646.

9. Smolander, K.; Melník, M. Acta Chem. Scand. A 1984, 38, 619.

10. Smolander, K. Acta Chem. Scand. A 1983, 37, 5.

11. Moncoľ, J.; Koman, M.; Melník, M.; Černáková, M.; Glowiak, T. Polyhedron 2000, 19, 2573.

12. Moncol, J.; Mudra, M.; Lönnecke, P.; Koman, M.; Melnik, M. J. Coord. Chem. 2004, 57, 1065.

13. Moncol, J.; Svorec, J.; Valko, M.; Melník, M.; Mazur, M.; Koman, M. Advences in Coordination, Bioinorganic, and Inorganic Chemistry; M. Melnik, J. Šima, M. Tatarko, Eds.; Slovak Technical University Press: Bratislava, 2005; pp. 240245.

14. Cahn, R.S.; Ingold, C.K. J. Chem. Soc. (London) 1951, 612.

15. (a) Horie, H.; Husebye, S.; Kato, M.; Meyers, E.A.; Muto, Y.; Suzuki, I.; Tokii, T.; Zingaro, R.A. Acta Chem Scand. A 1986, 40, 579. (b) Harada, A.; Tsuchimoto, M.; Ohba, S.; Iwasawa, K.; Tokii, T. Acta Crystallogr. B 1997, 53, 654. (c) Kawata, T.; Uekusa, H.; Ohbe, S.; Furukawa, T.; Tokii, T.; Muto, Y.; Kato, M. Acta Crystallogr. B 1992, 48, 253. (d) Koman, M.; Melnik, M.; Moncol, J.; Glowiak, T. Inorg. Chem. Comm. 2000, 3, 489. (e) Koreň, B.; Valach, F.; Sivý, P.; Melník, M. Acta Crystallogr. C 1985, 41, 1160. (f) Valach, F.; Tokarčík, M.; Maris, T.; Watkin, D.J.; Prout, C.K. J. Organomet. Chem. 2001, 622, 166. (g) Valach, F.; Koreň, B.; Tokarčík, M.; Melník, M. Chem. Papers 1998, 52, 140. (h) Melnik, M.; Koman, M.; Glowiak, T. Polyhedron 1998, 17, 1767. (i) Cingi, M.B.; Villa, A.C.; Manfredotti, A.G.; Gaustini, C. Cryst. Struct. Commun. 1972, 1, 363. (j) Bandoli, G.; Biagini, M.C.; Clemente, D.A.; Rizzardi, G. Inorg. Chim. Acta 1976, 20, 71.

16. Melník, M.; Näsänen, R. Suomen Kemistilehti B 1969, 42, 298.

17. Stoe \& Cie, $X$-RED v. 1.14; Darmstadt, Germany, 1999.

18. Main, P.; Fiske, S.J.; Hull, S.E.; Lessinger, L.; Germain, G.; Declerq, J.-P.; Woolfson, M.M. MULTAN-87, A System of Computer Programs for the Automatic Solution of Crystal Structures from X-Ray Diffraction Data. University of York: Englamd, and Louvain-la-Neuve: Belgium, 1987.

19. Hall, S.R.; Flack, H.D.; Stewart, J.M., Eds. XTAL3.2 User's Manual. University of Western Australia and Maryland 1992.

20. Farugia, L.J. J. Appl. Cryst. 1997, 30, 565.

21. Earnshaw, A. Introduction to Magnetochemistry. Academic Press: London, 1968.

22. (a) Melník, M. Coord. Chem. Rev. 1982, 47, 293. (b) Sundberg, M.R.; Uggla, R.; Melník, M. Polyhedron 1996, 15, 1157.

23. Yablokov, J.V.; Mosina, M.N.; Simonov, Yu.A.; Milkova, L.N.; Ablov, A.V. Zh . Strukt. Khim. 1978, 19, 42.

24. Cahn, R.S.; Ingold, Ch.; Prelog, V. Angew. Chem. Intern. Edit. 1966, 5,385

25. Flack, H.D. Acta Crystallogr. A 1983, 39, 876.

26. Janiak, C. J. Chem. Soc., Dalton Trans. 2000, 3885.

27. (a) Allan, F.H. Acta Crystallogr. B 2002, 58, 380. (b) Allan, F.H.; Motherwell, W.D.S. Acta Crystallogr. B 2002, 58, 407. 
28. Valach, F.; Tokarčík, M.; Maris, M.; Watkin, D.J.; Prout, C.K. Z. Kristallogr. 2000, 215, 56.

29. Havlicek, L.L.; Crain, R.D.; Practical Statistics for the Physical Sciences; American Chemical Society: Washington, DC 1988; pp. 109-110.

30. (a) Melník, M. Coord. Chem. Rev. 1982, 42, 259. (b) Mikloš, D.; Segla, P.; Palicová, M.; Kopcová, M.; Melník, M.; Valko, M.; Glowiak, T.; Korabik, M.; Mrozinski, J. Polyhedron 2001, $20,1867$.
31. Kahn, O. Molecular Magnetism, VCH publishers: Weinheim, 1993.

32. Melník, M.; Potočňák, I.; Macášková, L.; Mikloš, D. Polyhedron 1996, 15,2159 .

33. Abragam, A.; Bleaney, B. EPR of transition metal complexes, Clarendon Press: Oxford, 1970.

34. Yamanaka, M.; Uekusa, H.; Ohba, S.; Saito, Y.; Iwata, S.; Kato, M.; Tokii, T.; Muto, Y.; Steward, O.W. Acta Crystallogr. B 1992, 47,650 . 